\title{
Exponential Disruptive Technologies and the Required Skills of Industry 4.0
}

\author{
Ocident Bongomin $\left(\mathbb{D},{ }^{1}\right.$ Gilbert Gilibrays Ocen, ${ }^{2}$ Eric Oyondi Nganyi, ${ }^{1}$ Alex Musinguzi, ${ }^{1,3}$ \\ and Timothy Omara $\mathbb{i D}^{4,5}$ \\ ${ }^{1}$ Department of Manufacturing, Industrial and Textile Engineering, School of Engineering, Moi University, P.O. Box 3900-30100, \\ Eldoret, Kenya \\ ${ }^{2}$ Department of Electrical and Computer Engineering, Faculty of Engineering, Busitema University, P.O. Box 236, Tororo, Uganda \\ ${ }^{3}$ Department of Polymer, Industrial and Textile Engineering, Faculty of Engineering, Busitema University, \\ P.O. Box 236, Tororo, Uganda \\ ${ }^{4}$ Department of Chemistry and Biochemistry, School of Biological and Physical Sciences, Moi University, P.O. Box 3900-30100, \\ Eldoret, Kenya \\ ${ }^{5}$ Department of Quality Control and Quality Assurance, Product Development Directory, AgroWays Uganda Limited, Plot 34-60, \\ Kyabazinga Way, P.O. Box 1924, Jinja, Uganda
}

Correspondence should be addressed to Ocident Bongomin; ocidentbongomin@gmail.com

Received 26 October 2019; Accepted 12 December 2019; Published 7 February 2020

Academic Editor: Kevser Dincer

Copyright (c) 2020 Ocident Bongomin et al. This is an open access article distributed under the Creative Commons Attribution License, which permits unrestricted use, distribution, and reproduction in any medium, provided the original work is properly cited.

The $21^{\text {st }}$ century has witnessed precipitous changes spanning from the way of life to the technologies that emerged. We have entered a nascent paradigm shift (industry 4.0) where science fictions have become science facts, and technology fusion is the main driver. Thus, ensuring that any advancement in technology reach and benefit all is the ideal opportunity for everyone. In this study, disruptive technologies of industry 4.0 were explored and quantified in terms of the number of their appearances in published literature. The study aimed at identifying industry 4.0 key technologies which have been ill-defined by previous researchers and to enumerate the required skills of industry 4.0. Comprehensive literature survey covering the field of engineering, production, and management was done in multidisciplinary databases: Google Scholar, Science Direct, Scopus, Sage, Taylor \& Francis, and Emerald Insight. From the electronic survey, 35 disruptive technologies were quantified and 13 key technologies: Internet of Things, Big Data, 3D printing, Cloud computing, Autonomous robots, Virtual and Augmented reality, Cyber-physical system, Artificial intelligence, Smart sensors, Simulation, Nanotechnology, Drones, and Biotechnology were identified. Both technical and personal skills to be imparted into the human workforce for industry 4.0 were reported. The review identified the need to investigate the capability and the readiness of developing countries in adapting industry 4.0 in terms of the changes in the education systems and industrial manufacturing settings. This study proposes the need to address the integration of industry 4.0 concepts into the current education system.

\section{Introduction}

At present, industry 4.0 which differs in speed, scale, complexity, and transformative power as compared to the previous industrial revolutions can be considered as nascent [1]. Therefore, having prior insight into the speed and measure of the changes being brought by industry 4.0 is a prerequisite for success $[2,3]$. Industry 4.0 will increase the visibility of the existing inequalities among people, companies, and countries worldwide, as every country embraces its technologies in its own way [4]. African countries, for example, are embracing industry 4.0 at extremely slower rates vis-à-vis European countries [5, 6]. For survival in the industry 4.0 era, being knowledgeable about the changes and the speed at which they are occurring is indispensable. Thus, ensuring that any advancement in technology reach and 
benefit all is an ideal opportunity for everyone $[7,8]$. This is because industry 4.0 technologies are exponentially disruptive in nature [9].

Historically, technological innovations have been considered as the main drivers for sustainable economic development and productivity growth $[10,11]$. Further, they have been linked to changes in work and employment but this is not applicable to industry 4.0 [12]. This is because industry 4.0 emerged due to the fusion of technologies which are known to be exponentially growing and disruptive in a fashion expected to initiate rapid and massive disruption to all industrial sectors in terms of demand for occupations and skills [13]. Recently, advancement in disruptive technologies and industrial developments has been incisive towards industry 4.0 [14], which is popularized with diametrically different names in various countries. For instance, it is publicized as Made in China 2025 by China [15], Industrial Internet Consortium (IIC) and Smart Manufacturing Leadership in USA, and Robot Revolution Initiative (RRI) and Industrial Value Chain Initiative (IVI) in Japan [16].

Industry 4.0 is matchless with the preceding industrial revolutions owing to the substantial role its technologies play in wealth creation and socio-political stability $[17,18]$. However, the factors that triggered the past revolutions, which include among other various public and private initiatives, are also forthwith stimulating industry 4.0 developments [19]. The other unique factors which are the major drivers for industry 4.0 include the rapid technological developments and the need for singularities by the manufacturing companies [20]. Industry 4.0 will not only influence manufacturing industries as with the previous industrial revolutions but also leave footprints on the social, economic, and education sectors [21-23]. In point of fact, its influence on the education system has been under obsessive research in the recent years $[24,25]$. Thus, to secure most jobs, the requisite skills ought to be imparted into people through the right channel of education in higher institutions of learning [26].

Despite the rigorous research studies done by distinguished organizations such as the World Bank, World Economic Forum (WEF), and McKinsey Global Institute, the concept of industry 4.0 remains entirely nonconsensual $[27,28]$. Interestingly, industry 4.0 key technologies have been identified by these organizations and other academic researchers, though these technologies and their rankings dissent from one organization to another and amongst academic researchers $[29,30]$. For instance, World Economic Forum. [31] identified nine (9) key disruptive technologies, whereas the McKinsey Global Institute on the other hand reported twelve (12) key disruptive technologies of industry 4.0 [32]. Boston Consulting Group in their findings recognized nine (9) key disruptive technologies [33]. Contrastingly, Cheryl and Helena [34] singled out five (5) key disruptive technologies, well less than the ten (10) key disruptive technologies of industry 4.0 pointed out by Mashelkar [35]. The divergent sentiments and inferences drawn by previous researchers about the key technologies of industry 4.0 are quite exigent and can delude many interested researchers and practitioners. The exigency to clearly enumerate and comprehend the above-observed differences, explore and recognize the key technologies as well as the requisite skills of industry 4.0 instigated the present study. Thus, this paper is built on a comprehensive literature review aimed at determining the key technologies of industry 4.0 which are imposing disruption on all engineering fields especially mechanical and industrial engineering. A clear insight on the changes brought about by these technologies (particularly the key technologies) is a great opportunity to restructure and develop sustainable engineering as well as operator frameworks to accommodate these technologies.

\section{Methodology}

A comprehensive literature search was conducted in electronic databases: Google Scholar, Science Direct, Scopus, Sage, Taylor \& Francis, and Emerald Insight from February 2019 to August 2019 following procedures employed by Omara et al. [36]. The search was performed independently in all the databases and then combined with "or" and "and" operators. The multidisciplinary databases included original research articles published in peer-reviewed journals, books, thesis, dissertations, patents, and reports covering concepts on industry 4.0 between 2011 and 2019. Thus, articles in the returned results were assessed concerning their inclusion in this study, and further searches were carried out at the Google search engine using more general search terms to broaden the search, as follows: words such as "industry 4.0," "fourth industrial revolution," "Internet of things," "Big Data," "3D printing," "Cloud computing," "Autonomous robots," "Virtual reality, "Augmented reality," "Cyberphysical system," "Artificial intelligence," "Smart sensors," "Simulation," "Nanotechnology," "Drones," "Biotechnology," and "skills of industry 4.0" were used. The last search was done on 25 August 2019. The search outputs were saved where possible on databases, and the authors received notification of any new searches meeting the search criteria (from Science Direct, Scopus, and Google Scholar).

\section{Results and Discussion}

Only full-text results published in English between 2011 and 2019 were considered for this review.

3.1. Industry 4.0 Definition. The term "Industry 4.0" was coined by German's group of mechanical engineers in the year 2011 to account for the widespread integration and adaptation of ICT in manufacturing industries [18]. The definition of industry 4.0 is ambiguous, and no single definition has been conventionally adopted. The Institute of Technology Assessment (ITA) [37] defined industry 4.0 as a systemic change bringing about extensive changes in the way works are done. However, it is stressed that industry 4.0 is not just about the introduction of a new technology linked with an incremental adaptation of work systems as in the previous three industrial revolutions, but about an assemblage of novel technologies and forms of application, with discrete degrees of technical maturity and systemic effects. 
Simply put, industry 4.0 is a precipitous transition from the previous industrial revolutions (Table 1).

Schröder [39] defined industry 4.0 as the digital transformation in all areas of industrial processes and production effectuating a new paradigm shift in production systems. In addition, industry 4.0 has been defined as the massive developmental stage in industrial manufacturing including organisation and the management of the entire value chain [40], and its technologies are the blurring line between the physical, digital, and biological sphere of production or the manufacturing system [34]. An industry 4.0 definition modified from Cheryl and Helena [34] and Deloitte [40] has been adopted in the present study.

3.2. Exponential Disruptive Technologies. Industry 4.0 is being powered by exponentially growing disruptive technologies that inaugurate changes rapidly but at a nonlinear pace $[1,41]$. Besides, these technologies have a potential to cause broader societal transformation by changing the existing economic sectors, tenets of work, production, and consumption [42]. In the main, two types of technologies can be appreciated: sustaining and disruptive technologies; the former has a constant or incremental rate of improvement of existing customers, whereas the latter creates disruption on the status quo as it produces a unique set of values. The major implication of disruptive technology is the demand for new course content, employment, knowledge, and skills $[35,40,43]$.

In this scientometric survey, 35 disruptive technologies were identified in 70 publications (Table 2). Ranking of the technologies was done basing on the number of their appearances in the selected publications, as shown in Table 2. From the ranking results, 13 key technologies were identified as illustrated by the Pareto chart (Figure 1). The current and the future development and application areas of these key disruptive technologies are subsequently discussed.

3.3. Internet of Things (IoT). IoT is not just machine-tomachine (M2M) connectivity, but its definition spans beyond by creating an intelligent, invisible network fabric that can be sensed, controlled, and programmed through which the physical world objects become intelligent and communicate independently, online [95]. Characteristically, IoT is referred to as the internet of everything (IoE) [96]. The 'things' can be electronic sensors, actuators, other digital devices, or any other objects (e.g., people and buildings) [60]. The integration of internet to everything was meant to facilitate production systems $[51,97]$. In industries, IoT has been exploited in automation for lighting, heating, robotic vacuums, remote monitoring, and control of machines [51]. Despite it being a dateless technology, IoT has enormous innovative applications of its technologies [98]. For instance, automatic identification technology such as radio frequency identification (RFID) [99] and Beacons [100] is currently used to make any object (such as product) to become smart [101]. The other application domains of IoT include supply chain management, healthcare [102, 103], disaster vigilance, and recovery [104]. The IoT systems have also found application in predictive maintenance systems and real-time urban microclimate monitoring [105]. Most of the IoT applications have been classified as components of smart cities $[103,106]$.

Typical IoT architecture consists of three layers; (i) perception layers, (ii) network layers, and (iii) application layers [107]. The first layer functions as sensors for data acquisition. The second layer operates as a data transmission platform, and the last layer is the application layer in which the smart environment is created. Examples of smart environment include smart city, smart home, smart grid, and smart government [108]. The great barriers to IoT applications are cyber-attack (i.e., security and forensic challenges) and low connectivity. For these salient reasons, the major development of IoT during the move to industry 4.0 will focus on exploring innovative solutions that will pave way to secure forensically sound deployment of IoT networks $[109,110]$ as well as increase the IoT systems connectivity [111]. The foremost companies behind the IoT inventions and deployment include GE, IBM, CISCO, Google, Amazon, Microsoft, SAP, and AG [112]. These companies are, respectively, responsible for Microsoft Azure IoT, Oracle IoT cloud services, Google cloud IoT core, IBM Watson IoT, AWS IoT, and Bosch IoT suite IoT platform markets [113].

3.4. Big Data. The Big Data are rather distinct from the traditional data due to their large growing dataset [114]. Lately, Big Data have been defined in terms of huge datasets that consist of six main characteristics, namely, volume, variety, velocity, veracity, value, and complexity [115]. The intricacy of Big Data brought its own problem as it demands for new skills and knowledge [114, 116]. In addition, it has a pronounced impact on board level or stakeholders decision-making [117]. With the move to industry 4.0, the main application areas of Big Data include smart grid [118], smart meter [119], Internet of Things [120], E-health (notably pharmaceutical data, lab, and clinical data), public utilities (such as water supply and sewage system), transportation and logistics (for example, the number of passengers using buses and the number of accident occurring per year), and agricultural remote sensing (data obtained from soil moisture and temperature changes) [121]. Another application area of Big Data is the digital finance, where it is used as Big Data Credit Investment which fully utilizes modern digital information techniques [122]. Finally, Big Data have recently been adopted for massive open online course (MOOC) and its application in this area is expected to grow explosively in the era of industry 4.0 [123].

The major techniques commonly used in Big Data are relational and nonrelational data stores, computations, and MapReduce while the software frameworks in Big Data include Hadoop, Spark, Hive, and Google's BigQuery [124]. However, with the continuous advancement required to shape industry 4.0 movements, more advanced Big Data software frameworks that can handle extensively huge amounts of data are expected to emerge. 
TABLE 1: Industrial revolution transition.

\begin{tabular}{|c|c|c|c|}
\hline $\begin{array}{l}\text { Revolution and } \\
\text { timeline }\end{array}$ & Technologies and capabilities & Main industries & Main engineering discipline(s) \\
\hline $\begin{array}{l}\text { Industry } 1.0 \\
1760-1900\end{array}$ & $\begin{array}{l}\text { Mechanization using water and steam (first } \\
\text { mechanical weaving loom) }\end{array}$ & Coal, iron, textile & Mechanical engineering \\
\hline 2.0 & $\begin{array}{c}\text { Mass production using electricity (first } \\
\text { assembly line) }\end{array}$ & $\begin{array}{l}\text { Semiconductors, } \\
\text { automobiles, steel, airplanes }\end{array}$ & $\begin{array}{c}\text { Electrical engineering, industrial } \\
\text { engineering }\end{array}$ \\
\hline $\begin{array}{l}\text { Industry } 3.0 \\
1960-2000\end{array}$ & $\begin{array}{c}\text { Automation using digital electronics and IT } \\
\text { (first PLC system })^{1}\end{array}$ & $\begin{array}{l}\text { Electronics, mobile phones, } \\
\text { internet, computer, robots }\end{array}$ & $\begin{array}{c}\text { Computer and ele } \\
\text { software }\end{array}$ \\
\hline $\begin{array}{l}\text { Industry } 4.0 \\
2000 \text {-today }\end{array}$ & $\begin{array}{l}\text { Innovation based on the "fusion of virtual, } \\
\text { physical, digital, and biological sphere" (cyber- } \\
\text { physical production system) }\end{array}$ & $\begin{array}{l}\text { Social media, self-driving } \\
\text { cars, drones, virtual assistant }\end{array}$ & $\begin{array}{l}\text { Integration of many engineering } \\
\text { disciplines, e.g., mechatronic } \\
\text { engineering, biomechanical engineering }\end{array}$ \\
\hline
\end{tabular}

${ }^{1}$ PLC- programmable logic controller, modified from [1, 24, 38].

Table 2: Disruptive technologies of industry 4.0.

\begin{tabular}{|c|c|c|c|}
\hline Rank & Disruptive technology (search terms) & Appearances & References \\
\hline 1 & Internet of Things (IoT) & 33 & {$[1,8,15,16,22,25,27,29,40,43-66]$} \\
\hline 2 & $\begin{array}{c}\text { Big Data (data mining, data analytics, } \\
\text { and advanced algorithms) }\end{array}$ & 30 & {$[8,10,16,29,33,44,46,47,49-53,55,56,59,60,63-74]$} \\
\hline 3 & $\begin{array}{l}\text { Additive manufacturing (3D printing, } \\
\text { 3D scanning) }\end{array}$ & 28 & {$[1,7,8,10,33,40,47-59,61-67,69,75]$} \\
\hline 4 & Cloud computing & 27 & {$[8,10,29,33,44-46,48-50,52,53,55,56,59,63-67,69,70,72,76-78]$} \\
\hline 5 & $\begin{array}{c}\text { Autonomous robots (industrial robots, } \\
\text { robot arms) }\end{array}$ & 24 & {$[1,8,10,15,33,48,50-57,59,61,62,64,65,67,69,75,79]$} \\
\hline 6 & $\begin{array}{l}\text { Virtual reality (VR) and Augmented } \\
\text { reality (AR) }\end{array}$ & 21 & {$[8,10,33,47,50-53,55,56,61-66,69,75,80,81]$} \\
\hline 7 & Cyber-physical systems (CPS) & 20 & {$[8,15,16,24,25,27,29,44,46-48,52,56,66,69,70,72,82-85]$} \\
\hline 8 & $\begin{array}{c}\text { Artificial intelligence (AI) and machine } \\
\text { learning }\end{array}$ & 19 & {$[1,8,33,50,53-57,59,61,62,64-66,75,78,86]$} \\
\hline 9 & $\begin{array}{l}\text { Smart sensors (smart actuators, smart } \\
\text { objects, and smart dust) }\end{array}$ & 15 & {$[35,48,49,51,54,58,62,63,65,75,87-91]$} \\
\hline 10 & $\begin{array}{l}\text { Advanced simulation (3D modelling } \\
\text { and } 3 \mathrm{D} \text { visualization) }\end{array}$ & 15 & {$[33,35,40,49,52,56,64,65,69,75,79,91-94]$} \\
\hline 11 & $\begin{array}{l}\text { Nanotechnology (advanced materials, } \\
\text { nanomaterials, nanobots) }\end{array}$ & 13 & {$[40,51,53-55,57,59,62,64,75,86,89,91]$} \\
\hline 12 & Drones, UAV, UASs, and RPA ${ }^{1}$ & 10 & {$[8,35,40,51,54,55,62,65,75,92]$} \\
\hline 13 & $\begin{array}{c}\text { Biotechnology (synthetic biology, } \\
\text { molecular biology) }\end{array}$ & 10 & {$[35,40,53-55,57,59,62,86,91]$} \\
\hline 14 & $\begin{array}{c}\text { Block chain (Bitcoin, cryptocurrency, } \\
\text { digital currency) }\end{array}$ & 7 & {$[8,37,46,56,58,59,63]$} \\
\hline 15 & $\begin{array}{c}\text { Industrial Internet of Things (IIoT) or } \\
\text { industrial internet }\end{array}$ & 6 & {$[12,24,25,33,37,38]$} \\
\hline 16 & Cybersecurity & 6 & {$[37,48,49,54-56]$} \\
\hline 17 & Smart factory and intelligent factory & 5 & {$[8,15,16,24,26]$} \\
\hline 18 & Internet of services (IoS) & 5 & {$[8,27,29,37,48]$} \\
\hline 19 & $\begin{array}{c}\text { Vertical and horizontal }(\mathrm{V} \& \mathrm{H}) \text { system } \\
\text { integrations }\end{array}$ & 5 & {$[11,33,56,64,69]$} \\
\hline 20 & $\begin{array}{l}\text { Renewable energy and advanced energy } \\
\text { storage }\end{array}$ & 4 & {$[53,54,59,62]$} \\
\hline 21 & $\begin{array}{l}\text { Machine-to-machine communication } \\
\text { (M2M) }\end{array}$ & 4 & {$[8,29,57,67]$} \\
\hline 22 & $\begin{array}{c}\text { 5G network (advanced network } \\
\text { technology) }\end{array}$ & 4 & {$[49,56,58,73]$} \\
\hline 23 & $\begin{array}{l}\text { Information and communication } \\
\text { technology (ICT) }\end{array}$ & 3 & {$[16,44,46]$} \\
\hline 24 & Quantum computing & 3 & {$[53,54,62]$} \\
\hline
\end{tabular}


TABLE 2: Continued.

\begin{tabular}{|c|c|c|c|}
\hline Rank & Disruptive technology (search terms) & Appearances & References \\
\hline 25 & $\begin{array}{c}\text { Mobile devices (smartphones, smart } \\
\text { cameras) }\end{array}$ & 3 & {$[51,63,67]$} \\
\hline 26 & $\begin{array}{c}\text { Manufacturing execution system (MES) } \\
\text { and SCADA }\end{array}$ & 2 & {$[16,53]$} \\
\hline 27 & Neurotechnology & 2 & {$[59,62]$} \\
\hline 28 & Predictive maintenance & 2 & {$[72,75]$} \\
\hline 29 & $\begin{array}{l}\text { Advanced human to machine interface } \\
\text { (HMI) }\end{array}$ & 2 & {$[64,75]$} \\
\hline 30 & Material science & 1 & {$[54]$} \\
\hline 31 & Internet of data (IoD) & 1 & {$[53]$} \\
\hline 32 & Internet of energy (IoE) (smart grid) & 1 & {$[67]$} \\
\hline 33 & $\begin{array}{l}\text { Flexible production system (FMS) and } \\
\text { cluster concept }\end{array}$ & 1 & {$[50]$} \\
\hline 34 & $\begin{array}{l}\text { Location detection (digital traceability } \\
\text { and GPS) }\end{array}$ & 1 & {$[64]$} \\
\hline 35 & Digital twin & 1 & {$[75]$} \\
\hline
\end{tabular}

${ }^{1}$ UAV: unmanned aerial vehicle, RPA: remotely piloted aircraft, UASs: unmanned aircraft systems, ${ }^{2}$ SCADA: supervisory control and data acquisition, and ${ }^{3}$ GPS: global positioning system.

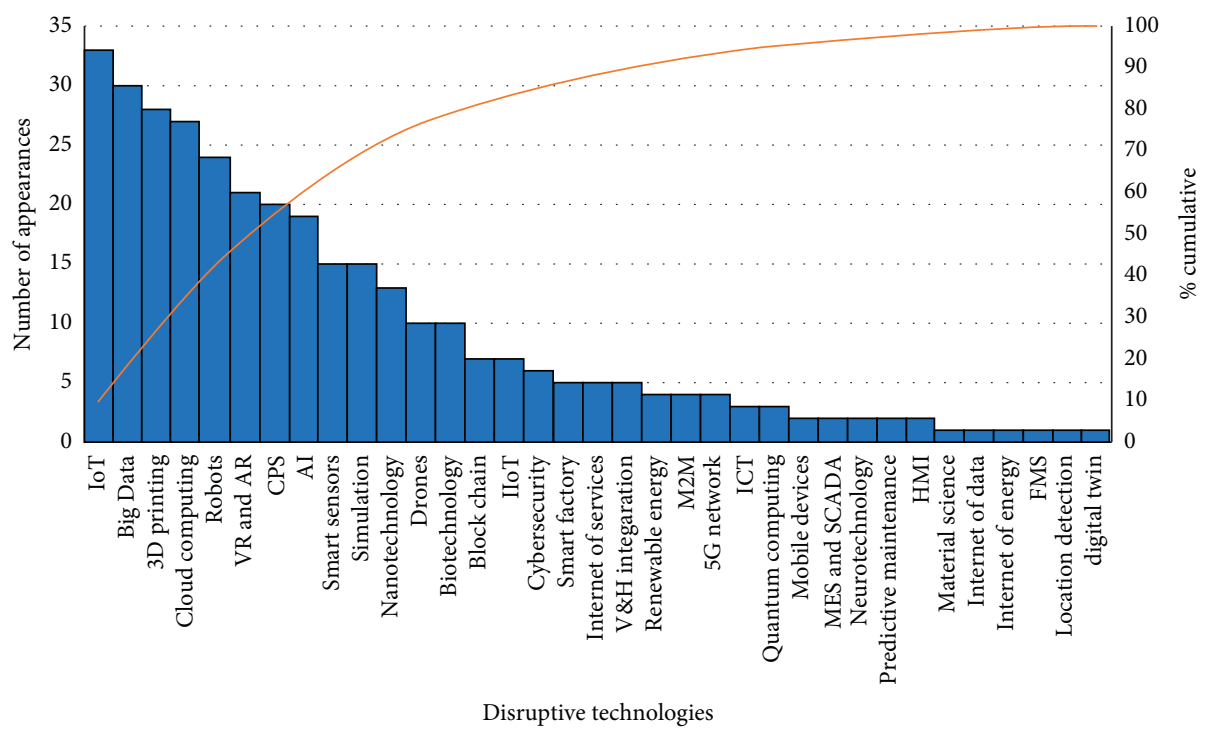

FIGURE 1: Identification of key disruptive technologies of industry 4.0 .

3.5. 3D Printing. 3D printing (additive manufacturing) unlike subtractive manufacturing is the technology that builds up physical objects based on the 3D CAD file by consecutive addition of liquid, sheet, or powdered materials [125]. The populously employed materials by $3 \mathrm{D}$ printers are plastics (such as polylactic acid, acrylonitrile butadiene styrene, and hydrogel composites [126, 127]) and metallic materials such as steel, stainless-steel, titanium, gold, and silver [128]. The recently developed materials used by 3D printers are liquid crystal elastomers and jammed microgel ink [129]. The technologies behind 3D printing advancement include nanoparticle jetting, laser engineering net shape, wire and arc additive manufacturing, electron beam melting, selective laser sintering/melting, atomic diffusion additive manufacturing, single-pass jetting, fused deposition modelling, direct ink printing, and filament extrusion method [130].
Universally, 3D printing has been applied to produce nearly everything, ranging from buildings to human organs (such as the kidney and the heart) and tissues (bones, muscles, and teeth) $[127,129,131,132]$. Though its application for printing body parts (3D bioprinting) is in its infancy, it is anticipated to rise astronomically with industry 4.0 movements [133]. Beyond, the growth of 3D printing will strategically explore innovations for bioproduction of living responsive materials (such as shape-memory polymers and aqueous droplet) and devices such as soft robots [134].

3.6. Cloud Computing. Cloud computing is a service model where computing services that are available remotely permit users to access applications and data and physical computation resources over a network, on demand or pay-per-use fashion $[135,136]$. The application domains of cloud 
computing technology in education include e-learning (such as curriculum content management, virtual lab environment, office productivity suite, library management, and collaborative learning), communication (e-mail and notifications), and administration (such as students registration management and human resources management) [137]. Cloud computing has not only been used in the education sector but also in other sectors such as healthcare [138], manufacturing, entertainment, transportation, and energy [139].

Over the years, cloud computing has been used for some enterprise and analytic applications, but in the era of industry 4.0, the performance of cloud technologies is expected to improve particularly following the security in both network application and host levels [135]. The main companies behind cloud computing development and deployment are Amazon, Microsoft, Google, and IBM. These cloud providers often implement inflexible pricing schemes for cloud users based on the duration [139].

3.7. Autonomous Robots. Autonomous robots as the name suggests, performs autonomous production more precisely and can work alongside humans or even in human-restricted places. They have the faculty to complete assigned tasks accurately and perspicaciously in time, focusing on safety, flexibility, versatility, and collaboratively [140], contrary to the olden days when robots were designed primarily to tackle complex assignments in manufacturing industries. The autonomous robots are also being utilized in logistics such as in warehouses and container terminals [141]. The development of autonomous robots has been continuously advancing to meet the need of industry 4.0 $[142,143]$. The major companies behind the autonomous robots' innovations and developments are Kuka, Rethink Robotics, Bionic robotics, Roberta Gomtec, Honda, ABB, and Fanuc. The autonomous robot architecture entails functional and decisional components [144] which with the upsurge of industry 4.0 will have to be developed as the exploration of new areas of applications of autonomous robots increases.

3.8. Virtual and Augmented Reality. Virtual reality (VR) and Augmented reality (AR) are complementary technologies of industry 4.0. With $\mathrm{VR}$, the users are transported, usually via a headset, into a virtual world while with $\mathrm{AR}$, applications present an illusion of layers of graphic information superimposed on some portion of the user's field of view [81]. In most cases, the two technologies are combined (also known as mixed reality) to yield gigantic applications by transcending the distance, time, and scale and increasing comprehension, teamwork, communication, and decisionmaking. Although AR is regarded as a developing technology with some of its technical manuals missing [145], it remains emblematic of industry 4.0 as it brings together the physical and digital worlds, and indeed, the public and the private sphere [67].

The foremost application domain of VR and AR has been in education since the 1990s to teach subjects like mathematics, geometry, physics, chemistry, and anatomy [146]. In the past few years, VR has been applied in virtual training. For instance, a virtual plant-operator training module is being used to train plant personnel to handle emergencies [147]. In maintenance, AR has been used for repairing and servicing complex systems such as hydraulic breakers [81, 148]. Other application areas of VR and AR include tourism, retail and fashion, business, marketing, storytelling, healthcare, defence, design, and development. The main companies behind the development of VR and AR are Google, Microsoft, Apple, and Espon. Examples of currently used AR smart glasses include Google Glasses, Microsoft HoloLens, Apple Headset, and Espon Moverio Pro BT-2000 [145].

3.9. Cyber-Physical System (CPS). CPS is referred to as a networked system in which the cyber or computational part is tightly integrated with the physical components. CPS uses multiple sensors such as touch, light, and force sensors to achieve distinct purposes. This makes CPS exceedingly discrete from just an embedded system [149]. Lately, CPS frameworks have been congruously utilized in various fields including manufacturing [150], laboratory, and teaching factory $[151,152]$. The latest development of CPS is the Mobile CPS that extends CPS application domains [153]. With the precipitous shift to industry 4.0, further development of CPS will focus on the protection of critical industrial systems, manufacturing lines, and other CPS application frameworks from cybersecurity threats. Consequently, secure and reliable communication as well as a sophisticated identity and access management of machines and users are very essential [153, 154]. Hence, CPS will be integrated with other technologies including IoT, cloud computing, and smart sensors to form the new smart CPS that will link the virtual, physical, and digital worlds. This will enable intelligent or smart objects to properly and rapidly communicate and interact with each other [154].

3.10. Artificial Intelligence (AI). AI is the knowledge-based and thinking program coded and designed in machines to imitate human or animal reasoning ability [155]. For the past few years, AI has been applied in complex operations such as drilling fluid, underground mining [156, 157], and maintenance, as well as monitoring of sophisticated manufacturing systems [158]. The emerging AI applications that are currently shaping industry 4.0 journey include self-driving cars, human speech and face recognition, and interpreting of complex data and medicines, for example, cardiovascular medicine) [159]. As we move to industry 4.0, AI advancement gear towards integration of AI technology with other technologies such as Big Data, cloud computing to perform gigantic tasks, and to widen their application in all fields. For example, a recent finding indicates that AI can be properly applied to handle infectious disease Big Data analytics in healthcare sectors [160]. Notable companies behind AI development include Google, SpaceX, Apple, GE, and Microsoft [159, 161]. 
3.11. Smart Sensors. Several types of smart sensors have been developed in the recent past to furnish the need of industry 4.0. These sensors are engineered in the manufacture of smart devices or objects such as smart dust, smart cameras, smartphones, and smart homes [162]. Smart sensors have been largely used for monitoring purposes [163]. Monitoring systems for water and flood levels, gas, environmental, structural health, and remote and equipment fault diagnostic systems, as well as advanced medical applications employ smart sensors $[162,164,165]$. In the industry 4.0 era, these smart sensors will be integrated with the IoT system and the advancement of smart sensors will continue to grow tremendously [166]. Smart homes, smart cities, and smart grids are now available because of various installed temperature, proximity, optical, pressure, and ultrasonic smart sensors $[167,168]$.

3.12. Simulation. Simulation is a routine method of analyzing the behaviour of complex systems. Simulation is a classical antiquity technology which dates far back to the era of analogue computers [169]. Nonetheless, its application has proliferated in different fields because of its demonstrated ability to improve components of manufacturing systems (products, materials and ergonomic design, energy consumption, production processes, and efficiency) [170], education, and other industrial sectors [171]. For example, in complex automobile manufacturing, ceramic production and chemical processes [172] and medical operation training in paediatric urology and surgery [173]. Additionally, it has been applied to study complex systems such as the cloudbased system [174] and group safety especially for underground miners [175].

Simulation is forecasted to advance swiftly due to the need to understand the behaviour of complex systems with the latest technological innovations in fields such as transportation, communication, medicine, and metrology. Evidently, simulation software developers are continuously advancing (updating) their software to meet the needs of industry 4.0, for example, Siemens, Rockwell Automation, MathWorks, and Festo, which are, respectively, developers of Solid edge, Arena, Simulink, and FluidSim software have released updated (latest) versions of these software [169].

3.13. Nanotechnology. Nanomaterials are the smallest materials with a singular unit within the nanoscale $(1-100 \mathrm{~nm})$ [176]. They evolved the following obsessive research in the field of materials science [177]. The ideology of nanotechnology is "science small" as it is the technology applied to produce nanomaterials. Though it is an aged technology, its novel and numerous innovative applications have paved the way for nanotechnology to industry 4.0 movements. It has been applied in making vital components in aerospace, automobile, construction, manufacturing, food processing and packaging fields $[178,179]$, medicine [180], and forensic science [181]. An emerging application of nanotechnology is in the production of the biofuels [182]. In the industry 4.0 age, the applications of nanotechnology in energy storage, lighting, and photovoltaics are extensively needed to support the popularly growing application areas of industry 4.0. Furthermore, medical and high-tech applications of nanotechnology will also continue to advance [183], especially in areas such as new materials for batteries, 3D printing [184], and DNA nanotechnology [185].

3.14. Drones. Drones, frequently called unmanned aerial vehicle (UAV), remotely piloted aircraft (RPA), and unmanned aircraft systems (UASs) [186], are aircrafts without pilots on board (flying robots) $[187,188]$. There are three main types of drones: rotary wing, fixed wing, and lighterthan-air. The most common drone configuration is multirotor with four, six, or eight propellers and made with very small, powerful, and affordable electronic components that are also used in smartphones. Some of the manufacturers of drones include Kuleuven, Delair, Vives, Vito, AltiGator, Flying-Cam, and Drone Matrix [189].

Initially, drones were considered as toys for children before they later got adopted as gadgets of leisure that are sent to the skies to shoot impressive photographs and highdefinition videos. In general, drones have been majorly used for entertainment and media [186]. However, with the move to industry 4.0, drones are being equipped with smart devices (sensors and cameras) combined with other technologies like Big Data analytics and machine learning. Significantly, this has widened its field of applications to agriculture [190, 191], energy and utility, entertainment and media, infrastructure [192], insurance, security, telecom, transport, logistics, space exploration [193], and wildlife monitoring [194].

3.15. Biotechnology. Biotechnology encompasses many fields such as synthetic biology, molecular biology, genetic biology, gene editing, proteomics, biomimicry, and genomes [195]. In the era of industry 4.0, synthetic biology will be more explored than any other fields of biotechnology. Synthetic biology is an emerging field where biology and engineering disciplines are in unison [196]. It has been cited as a lucrative technology in industry 4.0 movements. The main function of synthetic biology is to create different artificial biological pathways, devices, or organisms that can imitate the naturally-made biological systems [197, 198]. The main application domains of synthetic biology are in agriculture [197] and healthcare where it has been used in the treatment of complex diseases such as cancer. In the industry 4.0 epoch, synthetic biology will be extensively utilized in the field of renewable and clean energy with improved efficiency for power supply to many systems such as robots and selfdriving cars $[56,143]$.

\section{Skills of Industry 4.0}

4.1. Required Skills. In the industry 4.0 revolution, all skills are required. This is fundamentally because all the previously disconnected technologies and applications have come into convergence. However, the opus of the existing workforce will need to change to match the skills required to support the success of industry 4.0. Further, the 
development of novel technologies such as smart sensors, intelligent assistant, robots, and automation will continue to demand change in the types of skills as well as the labour landscape [199]. Eventually, there will be a great transition for job demand from lower-skilled to highly-skilled jobs $[200,201]$. In order to clearly describe the skill requirements for industry 4.0, the present study broadly categorized the required skills in two groups: technical and personal (soft) skills. The technical skills are required for highly technicalized tasks while soft skills are for the most part essential for teamwork on the shop floor level and communication in daily business. Technical skills are subcategorized into theory and expertise skills, hardware skills, and software and algorithm skills (digital skills) as recapitulated in Table 3.

4.2. Building Skills into the Workforce of Industry 4.0. There is a dire need to identify and develop the disciplines and the required missing abilities in order to build suitable skills into the workforce of industry 4.0 [202]. The following measures therefore need to be taken earnestly to prepare the workforce of the future.

Higher education institutions (universities and technical colleges) play a censorious role in shaping the societal transitions requisite for industry 4.0 movements. However, today's higher education was developed in context of the previous three industrial revolutions which do not provide the necessary skills for shaping industry 4.0 movements [203]. In addition, most manufacturing and service industries will no longer demand for specialist personnel but the generalists. Therefore, higher education especially the universities ought to properly and extensively educate and develop capacity for knowledge retention among the graduates to prepare them for a productive life necessary for the ever-changing labour landscape [207, 208].

Another crucial issue in building the skills of industry 4.0 is the need for diversifying education and credentialing systems. This can be achieved by empowering and encouraging the education market places especially online learning platforms (MOOC) to continuously put much effort to accommodate the widespread needs of those willing to learn [123]. In addition, employers are required to develop attitude towards training and retraining their workers. Also, self-teaching efforts by jobholders themselves should be encouraged [26]. More importantly, to survive in the job market of industry 4.0, there is a need to nurture human skills such that the AI is unable to replicate [209].

Additionally, skills of industry 4.0 can be built by developing new curriculum especially in the old field of studies such as industrial and mechanical engineering to incorporate industry 4.0 infrastructures. The development of these curricula can only be achieved through extensive research along this line. In the recent years, few research studies have been conducted in the area of curriculum development with industry 4.0 context. For instance, Sackey and Bester [207] examined the impact of industry 4.0 on the existing industrial engineering curriculum. More research is on-going to ensure curriculum development reaches all the technology and engineering fields of study [208]. Lensing and Friedhoff [210] recently designed a curriculum for the Internet of Things laboratory to foster creativity. Similarly, research on the knowledge management system to facilitate the creation of open and collaborative ecosystems and the exploitation of internal and external flows of knowledge has been conducted [211]. Nevertheless, the curriculum development in context to industry 4.0 should not only target the technical fields of study but also cut across other fields such as business, economics, and management studies [212, 213].

The advancement, evolution, or revolution in the education system that accommodates industry 4.0 technologies has been coined as Education 4.0 [214-218]. This learning technique is believed to enhance learners' ability to apply the new technology which will empower them to produce innovations and creativities according to the changes in their societies $[219,220]$. Education 4.0 is a new era of combining technology into almost every element in didactic education. The technology trend of the education system is quite similar to industrial revolution, as shown in Table 4. Therefore, governments and universities need to step-up and adopt Education 4.0 to produce skills for the workforce of industry 4.0.

Furthermore, the more crucible way to build the skills of industry 4.0 is through proper adaptation of the teaching/ learning factory concept. The learning factory is capable of imparting both technical and soft skills to the human workforce of industry 4.0 [225, 226]. The learning factory aims at incorporating the learning and working environment from which realistic and relevant learning experiences arise. The learning factory follows a two-way knowledge transfer channel (i.e., factory-to-classroom and lab-to-factory) in which manufacturing topics are the basis for new synergy models between academia and industry [227]. Recently, several learning factory frameworks have been developed including learning factory 4.0 to foster the acquisition of the requisite skills of industry 4.0 technologies [227]. For instance, Rauch et al. [228] presented 20 design guidelines for the development of industry 4.0 learning factories. One way to adapt the industry 4.0 learning factories is through collusion between academia and industry [229]. Besides the learning factory, virtual reality-based teaching methods are necessary to enhance the capabilities and skills of young engineers [230].

Lastly, the most fascinating way of building the workforce of industry 4.0 technologies is the ability to harness the Operator 4.0 concept [231]. The Operator 4.0 concept majorly aims to create human-cyber-physical production systems that improve the abilities of the operators [232]. It represents the "operator of the future," a smart and skilled operator who performs "work aided" by machines if and as needed. Moreover, it is a new design and engineering philosophy for adaptive production systems that mainly focus on treating automation as a further enhancement of the human's physical, sensorial, and cognitive capabilities using human cyber-physical system integration [221]. The operator 4.0 typology includes analytical, virtual, augmented, collaborative, heathy, smarter, social, and super- 
TABLe 3: Required skills of industry 4.0.

\begin{tabular}{lcc}
\hline \multicolumn{1}{|c}{ Theory and expertise skills } & Technical skills & $\begin{array}{c}\text { Software and algorithms skills } \\
\text { (digital skills) }\end{array}$ \\
\hline & Hardware skills & \\
& \\
& Mechanical and plant \\
engineering, automation \\
technology, mechatronics, \\
microsystems technology, \\
electronics, hydraulics, \\
specialized knowledge of \\
process skills, electrical \\
engineering, software, ICT, \\
statistical knowledge \\
manufacturing activities and \\
process, awareness of \\
ergonomics, designers, grid \\
optimization engineering, \\
manufacturing operations \\
mantegration, customizing \\
(process mapping)
\end{tabular}

Mechanical and plant engineering, automation technology, mechatronics, microsystems technology, electronics, hydraulics, specialized knowledge of nufacturing activities and process, awareness of
Knowledge of management, organizational and processual, understanding

Interdisciplinary/generic knowledge about technologies and organizations, understanding of legal affairs, product management, multiproject management, supply chain and support services, logistics, abilities in the STEM subjects (science, technology, engineering, and mathematics), general understanding of machine interactions, general interdisciplinary knowledge of methods
Maintenance, servicing and further development of the systems, training and continuous professional development, IT knowledge and abilities, data and information processing and analytics, ability to interact with modern interfaces (humanmachine/human-robot), awareness for IT security and data protection, computer programming/coding abilities, software engineering, data science, analytical/logic thinking, data/Big Data analytics, visualization, Internet of Things (IoT), IT architecture, digital media, virtual modelling, information complexity and data management, process simulation knowledge, server's knowledge, emotional intelligence
Personal (soft) skills

Self and time management, adaptability and ability to change, team-working abilities, social skills, communication skills, trust in new technology, creativity, design, innovation, leadership, mindset for continuous improvement and lifelong learning, complexity, abstraction and problem-solving, self-directed action, selforganization, project management, human interaction, languages (English, German, etc.), autonomy, cognitive flexibility, responsibility, reliability, service orientation, negotiation, critical thinking, people management, coordinating, decision-making, service orientation 
TABLe 4: Paradigm shift in industry, education, and operator.

\begin{tabular}{|c|c|c|}
\hline $\begin{array}{l}\text { Industrial } \\
\text { revolution }\end{array}$ & Education (r)evolution (methods) & Operator (r)evolution (techniques) \\
\hline Industry 1.0 & Education 1.0 (dictation and direct transfer of information) & $\begin{array}{c}\text { Operator } 1.0 \text { (manual and dextrous work) (machine } \\
\text { tools) }\end{array}$ \\
\hline Industry 2.0 & Education 2.0 (progressivism and openness to internet) & Operator 2.0 (assisted work with $\mathrm{CNC})^{1}$ \\
\hline Industry 3.0 & $\begin{array}{c}\text { Education } 3.0 \text { (knowledge production and co- } \\
\text { constructivism) }\end{array}$ & Operator 3.0 (cooperative work with robot) \\
\hline Industry 4.0 & $\begin{array}{c}\text { Education } 4.0 \text { (innovation production and classroom } \\
\text { replacement) }\end{array}$ & Operator 4.0 (work aided by human-CPS) ${ }^{2}$ \\
\hline
\end{tabular}

${ }^{1} \mathrm{CNC}$ : computer numerical control and ${ }^{2} \mathrm{CPS}$ : cyber physical system. Modified from [219, 221-224].

strength operators [221, 222, 233]. Into the bargain, several operator frameworks are being developed to accommodate industry 4.0 technologies. One of the latest studies done by Golan et al. [234] developed operator-workstation interaction 4.0 to improve operator safety, performance, well-being, and satisfaction as well as the factory's production measures. Like the education system, the mode of operation has been transforming in accordance with the industrial revolution as shown in Table 4.

\section{Conclusions and Recommendations}

The present study identified differences in the view of previous researchers on the key technologies of industry 4.0. These differences were due to the different scopes of the case studies undertaken by the researchers. This is because industry 4.0 technologies are being adopted among countries or industries at different paces. Most investigations focused their case studies on countries like China, USA, Germany, UK, South Africa, Korea, Russia, Philippines, and Malaysia. This accounts for the differences because these countries have different capabilities in terms of resources, knowledge, and finances to implement industry 4.0 technologies. Thus, 35 disruptive technologies were explored and 13 key disruptive technologies were identified. This implies that the rate of industry 4.0 adaptation has been increasing among countries and industries over the years. The race among countries and companies towards industry 4.0 will further increase the rate of adaptation of these technologies. However, the more the industry 4.0 implementations, the more the skills required to support its growth will be needed. In essence, several frameworks such as Learning factory 4.0, Education 4.0, and Operator 4.0 have evolved to foster acquisition of the requisite skills of industry 4.0. Despite the tremendous efforts imposed by Western countries to ensure success in the industry 4.0 journey, most African countries seem unaware of this disruptive transformation. Thus, the capability and readiness of developing countries in adapting industry 4.0 in terms of the changes in the education systems and industrial manufacturing settings are also worth investigating.

\section{Conflicts of Interest}

The authors declare that there are no conflicts of interest regarding the publication of this paper.

\section{Acknowledgments}

Authors OB and TO are grateful to the World Bank and the Inter-University Council of East Africa for the scholarships awarded to them through the Africa Center of Excellence II in Phytochemicals, Textiles, and Renewable Energy (ACE IIPTRE) at Moi University, Kenya, which led to the realization of this communication.

\section{References}

[1] M. Xu, J. M. David, and S. H. Kim, "The fourth industrial revolution: opportunities and challenges," International Journal of Financial Research, vol. 9, no. 2, pp. 90-95, 2018.

[2] B. Kajanth, Industry 4.0: Securing the Future for German Manufacturing Companies, University of Twente, Enschede, Netherlands, 2016.

[3] B. Rick, M. Adam, L. Stephen, H. Marty, and S. Brenna, "The smart factory; responsive, adaptive, connected manufacturing," 2017.

[4] Y. Liao, L. Eduardo Rocha, F. Deschamps, G. Brezinski, and V. André, "The impact of the fourth industrial Revolution : a cross-country/region comparison," Production, vol. 28, Article ID e20180061, 2018.

[5] Deloitte, "Industry 4.0: is africa ready for digital transformation?" 2016.

[6] W. Naudé, "Entrepreneurship, education and the fourth industrial revolution in Africa," IZA DP No. 10855, Maastricht University, Maastricht, Netherlands, 2017.

[7] L. M. N. Daniel, V. Alencastro, L. G. Q. Osvaldo et al., "Exploring industry 4.0 technologies to enable circular economy practices in a manufacturing context: a business model proposal," Journal of Manufacturing Technology Management, vol. 30, no. 3, pp. 607-627, 2019.

[8] M. Lee, J. J. Yun, A. Pyka et al., "How to respond to the fourth industrial revolution, or the second information technology revolution? Dynamic new combinations between technology, market and society through open innovation," Journal of Open Innovation, vol. 21, no. 3, pp. 1-24, 2018.

[9] M. Chiarvesio and R. Romanello, "Chapter 14 industry 4.0 technologies and internationalization: insights from Italian companies," Progress in International Business Research, vol. 13, pp. 357-378, 2018.

[10] I. Dorleta, G. Jaione, and I. I. Juan, "Business model innovation through industry 4.0: a review," Procedia Manufacturing, vol. 22, pp. 4-10, 2018.

[11] T. Stock and G. Seliger, "Opportunities of sustainable manufacturing in industry 4.0," Procedia CIRP, vol. 40, pp. 536-541, 2016. 
[12] J. M. Müller, K. Daniel, and V. Kai-Ingo, "What drives the implementation of industry 4.0 ? The role of opportunities and challenges in the context of sustainability," Sustainability, vol. 247, no. 10, pp. 1-24, 2018.

[13] S. Pi-Shen, J. Janice, S. John, and H. Ann-Louise, The Fourth Industrial Revolution: The Implications of Technological Disruption for Australian VET, NCVER, Adelaide, Australia, 2018.

[14] E. Paravizo, O. C. Chaim, D. Braatz, B. Muschard, and H. Rozenfeld, "Exploring gamification to support manufacturing education on industry 4.0 as an enabler for innovation and sustainability," Procedia Manufacturing, vol. 21, pp. 438-445, 2018.

[15] L. Li, "China's manufacturing locus in 2025: with a comparison of "Made-in-China 2025" and "Industry 4.0"," Technological Forecasting and Social Change, vol. 135, pp. 66-74, 2018.

[16] R. Y. Zhong, X. Xu, E. Klotz, and S. T. Newman, "Intelligent manufacturing in the context of industry 4.0: a review," Engineering, vol. 3, no. 5, pp. 616-630, 2017.

[17] M. Schäfer, "The fourth industrial revolution: how the EU can lead it," European View, vol. 17, no. 1, pp. 5-12, 2018.

[18] S. Günther, A. Reiner, J. Gausemeier, T. H. Michael, and W. Wolfgang, "Industrie 4.0 maturity index," in Managing the Digital Transformation of Companies (Acatech STUDY Series), Acatech, Munich, Germany, 2017.

[19] L. Gehrke, D. Rule, C. Bellmann et al., Industry 4.0. A Discussion of Qualifications and Skills in the Factory of the Future: A German and American Perspective, VDI and ASME Project, Düsseldorf, Germany, 2015.

[20] J. W. Strandhagen, E. Alfnes, J. O. Strandhagen, and L. R. Vallandingham, "The fit of industry 4.0 applications in manufacturing logistics: a multiple case study," Advances in Manufacturing, vol. 5, no. 4, pp. 344-358, 2017.

[21] R. Morrar, H. Arman, S. Mousa, and K. Schwab, "The fourth industrial revolution (industry 4.0): a social innovation perspective," Technology Innovation Management Review, vol. 7, no. 11, pp. 12-20, 2017.

[22] E. G. Popkova and B. S. Sergi, "Will industry 4.0 and other innovations impact Russia's development?" in Exploring the Future of Russia's Economy and Markets, pp. 51-68, Emerald Publishing Limited, Bingley, UK, 2018.

[23] T. K. Sung, "Industry 4.0: a Korea perspective," Technological Forecasting and Social Change, vol. 132, pp. 40-45, 2018.

[24] K.-D. Thoben, S. Wiesner, and T. Wuest, "“Industrie 4.0" and smart manufacturing - a review of research issues and application examples," International Journal of Automation Technology, vol. 11, no. 1, pp. 4-16, 2017.

[25] E. Mo, D. Centea, I. Singh, and T. Wanyama, "SEPT learning factory for industry 4.0 education and applied research," Procedia Manufacturing, vol. 23, pp. 249-254, 2018.

[26] B. Andrea and T. Jiř́, "Requirements for education and qualification of people in industry 4.0," Procedia Manufacturing, vol. 11, pp. 2195-2202, 2017.

[27] A. C. Pereira and F. Romero, "A review of the meanings and the implications of the industry 4.0 concept," Procedia Manufacturing, vol. 13, pp. 1206-1214, 2017.

[28] M. Crnjac, V. Ivica, and N. Banduka, "From concept to the introduction of industry 4.0," International Journal of Industrial Engineering and Management (IJIEM), vol. 8, no. 1, pp. 21-30, 2017.

[29] H. Mario, P. Tobia, and B. Otto, "Design principles for industrie 4.0 scenarios: a literature review," Technische Universität Dortmund, Lukasstrasse, Switzerland, No. 01/2015, 2015.
[30] B. Chen, J. Wan, L. Shu, P. Li, M. Mukherjee, and B. Yin, "Smart factory of industry 4.0: key technologies, application case, and challenges," IEEE Access, vol. 6, pp. 6505-6519, 2018.

[31] World Economic Forum (WEF), The Future of Jobs; Employment, Skills and Workforce Strategy for the Fourth Industrial Revolution, World Economic Forum (WEF), Geneva, Switzerland, 2016.

[32] J. Manyika, M. Chui, J. Bughin, R. Dobbs, P. Bisson, and A. Marrs, Disruptive Technologies: Advances that Will Transform Life, Business, and the Global Economy, 2013.

[33] R. Michael, L. Markus, G. Philipp et al., Industry 4.0: The Future of Productivity and Growth in Manufacturing Industries, Boston Consulting Group, Inc., Boston, Munich, USA, 2015.

[34] M. Cheryl and L. Helena, "Technology and innovation for the future of production: accelerating value creation," World Economic Forum, Geneva, Switzerland, White Paper No. 00030896, 2017.

[35] R. A. Mashelkar, "Exponential technology, industry 4.0 and future of jobs in India," Review of Market Integration, vol. 10, no. 2, pp. 1-20, 2018.

[36] T. Omara, S. Kagoya, A. Openy et al., "Antivenin plants used for treatment of snakebites in Uganda: ethnobotanical reports and pharmacological evidences," Tropical Medicine and Health, vol. 48, 16 pages, 2020.

[37] Institute of Technology Assessment (ITA), "Effects of industry 4.0 on vocational education and training," Institute of Technology Assessment (ITA), Vienna, Austria, ITA-15-04, 2015.

[38] R. Davies, "Industry 4.0: digitalisation for productivity and growth,” EPRS-PE 568.337, 2015.

[39] C. Schröder, "The Challenges of Industry 4.0 for Small and Medium-Sized Enterprises," 2017.

[40] Deloitte, Industry 4.0; Challenges and Solutions for the Digital Transformation and Use of Exponential Technologies, Deloitte, Zurich, Switzerland, 2015.

[41] Deloitte, "Exponential technologies in manufacturing. Transforming the future through technology," Talent and the Innovation Ecosystem, 2018.

[42] M. Burri, Current and Emerging Trends in Disruptive Technologies: Implications for the Present and Future of EU'S Trade Policy, Switzerland, 2017.

[43] D. Leipziger and V. Dodev, Disruptive Technologies and Their Implications for Economic Policy: Some Preliminary Observations, IIEP-WP-2016-13, 2016.

[44] V. Roblek, M. Meško, and A. Krapež, "A complex view of industry 4.0," SAGE Open, pp. 1-11, 2016.

[45] M. Faheem, S. B. H. Shah, R. A. Butt et al., "Smart grid communication and information technologies in the perspective of Industry 4.0: opportunities and challenges," Computer Science Review, vol. 30, pp. 1-30, 2018.

[46] M. Lezzi, M. Lazoi, and A. Corallo, "Cybersecurity for industry 4.0 in the current literature: a reference framework," Computers in Industry, vol. 103, pp. 97-110, 2018.

[47] Y. Lu, "Industry 4.0: a survey on technologies, applications and open research issues," Journal of Industrial Information Integration, vol. 6, pp. 1-10, 2017.

[48] S. Mittal, M. A. Khan, D. Romero, and T. Wuest, "A critical review of smart manufacturing \& industry 4.0 maturity models: implications for small and medium-sized enterprises (SMEs)," Journal of Manufacturing Systems, vol. 49, pp. 194-214, 2018. 
[49] C. Santos, A. Mehrsai, A. C. Barros, M. Araújo, and E. Ares, "Towards industry 4.0: an overview of European strategic roadmaps," Procedia Manufacturing, vol. 13, pp. 972-979, 2017.

[50] L. Santos, G. Brittes, N. Fabián, and A. Germán, “The expected contribution of industry 4.0 technologies for industrial performance," International Journal of Production Economics, vol. 204, pp. 383-394, 2018.

[51] A. Moktadir, S. M. Ali, S. Kusi-sarpong, and A. A. Shaikh, "Assessing challenges for implementing industry 4.0: implications for process safety and environmental protection," Process Safety and Environmental Protection, vol. 117, pp. 730-741, 2018.

[52] D. Vuksanovi, J. Ugarak, and D. Korčok, "Industry 4.0: the future concepts and new visions of factory of the future development," in Proceedings of the International Scientific Conference - Sinteza 2016, pp. 293-298, 2016.

[53] M. Ghobakhloo, "The future of manufacturing Industry: a strategic roadmap toward industry 4.0," Journal of Manufacturing Technology Management, vol. 29, no. 6, pp. 910-936, 2018.

[54] M. Joshua, The Fourth Industrial Revolution Launches into Space, Japan SPOTLIGHT, pp. 12-15, 2018.

[55] ADB and WEF, What Does the Fourth Industrial Revolution Mean for Regional Economic Integration? WEF, Cologny, Switzerland, 2017.

[56] B. Combes, D. Nassiry, L. Fitzgerald, and T. Moussa, Emerging and Exponential Technologies: New Opportunities for Low-Carbon Development, CDKN, London, UK, 2017.

[57] A. Petrillo, F. De Felice, R. Cioff, A. Petrillo, and F. De Felice, Fourth Industrial Revolution: Current Practices, Challenges, and Opportunities, Intech, London, UK, 2018.

[58] Access Partnership, Delivering the Fourth Industrial Revolution: The Role of Government, Access Partnership, London, UK, 2017.

[59] European Parliament Office (EPO), Patents and the Fourth Industrial Revolution: The Inventions behind Digital Transformation, European Parliament Office (EPO), Munich, Germany, 2017.

[60] D. P. Elmer, B. C. Alvin, G. A. Ramon et al., "preparing the philippines for the fourth industrial revolution: a scoping study," PIDS-Discussion paper seies No. 2018-11, Philippine Institute for Development Studies, Quezon, Philippines, 2018.

[61] F. Chiarello, L. Trivelli, A. Bonaccorsi, and G. Fantoni, "Computers in Industry Extracting and mapping industry 4.0 technologies using wikipedia," Computers in Industry, vol. 100, pp. 244-257, 2018.

[62] World Economic Forum (WEF), Technology and Innovation for the Future of Production: Accelerating Value Creation, World Economic Forum (WEF), Cologny, Switzerland, 2017.

[63] World Economic Forum (WEF), Harnessing the Fourth Industrial Revolution for Oceans, World Economic Forum (WEF), Cologny, Switzerland, 2017.

[64] PwC, Global Industry 4.0 Survey: Building the Digital Enterprise, PwC, London, UK, 2016.

[65] Ministry of International Trade and Industry Malasiaya, National Industry 4.0 Policy Framework, Ministry of International Trade and Industry Malasiaya, Kuala Lumpur, Malaysia, 2018.

[66] A. G. Frank, L. S. Dalenogare, and N. F. Ayala, "Industry 4.0 technologies: implementation patterns in manufacturing companies," International Journal of Production Economics, vol. 210, pp. 15-26, 2019.

[67] UNIDO, Industry 4.0: Opportunities behind the Challenge, Background Paper, UNIDO, Vienna, Austria, 2017.

[68] K. Santos, E. Loures, F. Piechnicki, and O. Canciglieri, "Opportunities assessment of product development process in industry 4.0," Procedia Manufacturing, vol. 11, pp. 1358-1365, 2017.

[69] S. S. Fernández-Miranda, M. Marcos, M. E. Peralta, and F. Aguayo, "The challenge of integrating industry 4.0 in the degree of mechanical engineering," Procedia Manufacturing, vol. 13, pp. 1229-1236, 2017.

[70] S. Vaidya, P. Ambad, and S. Bhosle, "Industry 4.0 - a glimpse," Procedia Manufacturing, vol. 20, pp. 233-238, 2018.

[71] R. Schmidt, M. Möhring, R.-C. Härting, C. Reichstein, P. Neumaier, and P. Jozinović, "Industry 4.0 - potentials for creating smart products: empirical research results," Business Information Systems, vol. 2, pp. 16-27, 2015.

[72] J. Lee, H.-A. Kao, and S. Yang, "Service innovation and smart analytics for industry 4.0 and big data environment," Procedia CIRP, vol. 16, pp. 3-8, 2014.

[73] J. Wan, "Industrie 4.0 : enabling technologies," in Proceedings of 2015 International Conference on Intelligent Computing and Internet of Things, pp. 135-140, Harbin, China, January 2015.

[74] R. Kumar, S. P. Singh, and K. Lamba, "Sustainable robust layout using Big Data approach: a key towards industry 4.0," Journal of Cleaner Production, vol. 204, pp. 643-659, 2018.

[75] Prime Minister's Industry 4 Taskforce, Industry 4.0 Testlabs in Australia Preparing for the Future, Hawthorn, Victoria, Australia, 2017.

[76] U. M. Dilberoglu, B. Gharehpapagh, U. Yaman, and M. Dolen, "The role of additive manufacturing in the era of industry 4.0," Procedia Manufacturing, vol. 11, pp. 545-554, 2017.

[77] D. Mishra, R. B. Roy, S. Dutta, S. K. Pal, and D. Chakravarty, "A review on sensor based monitoring and control of friction stir welding process and a roadmap to industry 4.0," Journal of Manufacturing Processes, vol. 36, pp. 373-397, 2018.

[78] K. Ooi, V. Lee, G. W. Tan, T. Hew, and J. Hew, "Cloud computing in manufacturing: the next industrial revolution in Malaysia?" Expert Systems with Applications, vol. 93, pp. 376-394, 2017.

[79] Microsoft, Winning in the Fourth Industrial Revolution: How the Financial Sector Must Transform Digitally to Lead the Race for Relevance, 2017.

[80] M. Dopico, A. Gomez, D. De la Fuente, N. García, R. Rosillo, and J. Puche, "A vision of industry 4.0 from an artificial intelligence point of view," in Proceedings of the International Conference on Artificial Intelligence, pp. 407-413, Bangkok, Thailand, 2016.

[81] M. Gattullo, G. W. Scurati, M. Fiorentino, A. E. Uva, F. Ferrise, and M. Bordegoni, "Towards augmented reality manuals for industry 4.0: a methodology," Robotics and Computer-Integrated Manufacturing, vol. 56, pp. 276-286, 2019.

[82] G. Wally, M. Gattullo, M. Fiorentino, F. Ferrise, M. Bordegoni, and A. Emmanuele, "Converting maintenance actions into standard symbols for augmented reality applications in industry 4.0," Computers in Industry, vol. 98, pp. 68-79, 2018. 
[83] C. O. Klingenberg, "Industry 4.0 : what makes it a revolution?" in Proceedings of the EurOMA, pp. 1-11, Edinburgh, UK, 2017.

[84] S. Wang, J. Wan, D. Zhang, D. Li, and C. Zhang, "Towards smart factory for industry 4.0: a self-organized multi-agent system with big data based feedback and coordination," Computer Networks, vol. 101, pp. 158-168, 2016.

[85] J. Lee, B. Bagheri, and H. Kao, "A cyber-physical systems architecture for industry 4.0-based manufacturing systems," Manufacturing Letters, vol. 3, pp. 18-23, 2014.

[86] A. S. Ullah, "Modeling and simulation of complex manufacturing phenomena using sensor signals from the perspective of industry 4.0," Advanced Engineering Informatics, vol. 39, pp. 1-13, 2019.

[87] World Economic Forum (WEF), Readiness for the Future of Production Report 2018, World Economic Forum, Cologny, Switzerland, 2018.

[88] S. Mittal, M. A. Khan, D. Romero, and T. Wuest, "Smart manufacturing: characteristics, technologies and enabling factors," Proceedings of the Institution of Mechanical Engineers, Part B: Journal of Engineering Manufacture, vol. 233, no. 5, pp. 1342-1361, 2019.

[89] A. Venkatachalam and K. Fukunari, Empowering ASEAN for the Circular Economy, Economic Research Institute for ASEAN and East Asia (ERIA), Jakarta, Indonesia, 2018.

[90] D. Vuksanović, J. Ugarak, and D. Korčok, "Industry 4.0: the future concepts and new visions of factory of the future development," Advanced Engineering Systems, pp. 1-7, 2016.

[91] C. Cimini, G. Pezzotta, R. Pinto, and S. Cavalieri, "Industry 4.0 technologies impacts in the manufacturing and supply chain Landscape : an overview," in Proceedings of SOHOMA 2018, pp. 1-13, Dalmine, Italy, 2018.

[92] UNIDO, Industry 4.0: The Opportunities behind the Challenge, Vienna International Centre, Vienna, Austria, 2018.

[93] V. Cruz-machado, V. Alcácer, and V. Cruz-machado, "Scanning the industry 4.0: a literature review on technologies for manufacturing systems," Engineering Science and Technology, vol. 22, no. 3, pp. 899-919, 2019.

[94] European Commission, Industry 4.0-Opportunities and Challenges for SMEs in the North Sea Region: Desk Study, European Commission, Brussels, Belgium, 2018.

[95] J. Chase, The Evolution of the Internet of Things, Texas Instruments, Dallas, TX, USA, 2013.

[96] K. Witkowski, "Internet of things, big data, industry 4.0innovative solutions in logistics and supply chains management," Procedia Engineering, vol. 182, pp. 763-769, 2017.

[97] L. Changhong and R. Y. Zhong, "Internet of things for manufacturing in the context of industry 4.0," Transdisciplinary Engineering: A Paradigm Shift, pp. 1013-1022, 2017.

[98] E. Oriwoh, P. Sant, and G. Epiphaniou, "Guidelines for internet of things deployment approaches - the thing commandments," Procedia Computer Science, vol. 21, pp. 122-131, 2013.

[99] Y. P. Raiwani, "Internet of Things : a new paradigm," International Journal of Scientific and Research Publications, vol. 3, no. 4, pp. 1-4, 2013.

[100] P. Nowodzinski, A. Puto, and L. Katarzyna, "Internet of things (IoT) in A retail environment. The new strategy for firm's development," European Scientific Journal, pp. 332341, 2016.

[101] T. Saarikko, U. H. Westergren, and T. Blomquist, "The Internet of Things: are you ready for what's coming?" Business Horizons, vol. 60, no. 5, pp. 667-676, 2017.
[102] G. Manogaran, R. Varatharajan, D. Lopez, P. M. Kumar, R. Sundarasekar, and C. Thota, "A new architecture of internet of things and big data ecosystem for secured smart healthcare monitoring and alerting," Future Generation Computer Systems, vol. 82, pp. 375-387, 2018.

[103] S. Albishi, B. Soh, A. Ullah, and F. Algarni, "Challenges and solutions for applications and technologies in the internet of things," Procedia Computer Science, vol. 124, pp. 608-614, 2018.

[104] K. Govinda and R. A. Saravanaguru, "Review on IOT technologies," International Journal of Applied Engineering Research, vol. 11, no. 4, pp. 2848-2853, 2016.

[105] P. Rathore, A. S. Rao, S. Rajasegarar, E. Vanz, J. Gubbi, and M. Palaniswami, "Real-time urban microclimate analysis using internet of things," IEEE Internet of Things Journal, vol. 5, no. 2, pp. 500-511, 2018.

[106] L. Dong, R. Mingyue, and M. Guoying, "Application of internet of things technology on predictive maintenance system of coal equipment," Procedia Engineering, vol. 174, pp. 885-889, 2017.

[107] P. P. Ray, "A survey on internet of things architectures," Journal of King Saud University-Computer and Information Sciences, 2016.

[108] D. Miorandi, S. Sicari, F. De Pellegrini, and I. Chlamtac, "Ad hoc networks internet of Things: vision, applications and research," Ad Hoc Networks, vol. 10, no. 7, pp. 1497-1516, 2012.

[109] M. Conti, A. Dehghantanha, K. Franke, and S. Watson, "Internet of things security and forensics: challenges and opportunities," Future Generation Computer Systems, vol. 78, pp. 544-546, 2018.

[110] I. Yaqoob, I. A. T. Hashem, A. Ahmed, S. M. A. Kazmi, C. S. Hong, and C. Hong Seon, "Internet of things forensics: recent advances, taxonomy, requirements, and open challenges," Future Generation Computer Systems, vol. 92, pp. 265-275, 2019.

[111] S. Li, S. Zhao, and S. Zhao, "5G internet of things : a survey," Journal of Industrial Information Integration, 2018.

[112] Advantech, Industry 4.0, Advantech, Taipei, Taiwan, 2015.

[113] J. K. Gerrikagoitia, G. Unamuno, E. Urkia, and A. Serna, "Digital manufacturing platforms in the industry 4.0 from private and public perspectives," Applied Sciences, vol. 9, no. 14, p. $2934,2019$.

[114] A. Oussous, F.-Z. Benjelloun, A. Ait Lahcen, and S. Belfkih, "Big Data technologies: a survey," Journal of King Saud University - Computer and Information Sciences, vol. 30, no. 4, pp. 431-448, 2018.

[115] M. Mohammadpoor and F. Torabi, "Big Data analytics in oil and gas industry: an emerging trend," Petroleum, 2019.

[116] A. De Mauro, M. Greco, M. Grimaldi, and P. Ritala, "Human resources for big data Professions : a systematic classification of job roles and required skill sets," Information Processing and Management, vol. 54, no. 5, pp. 807-817, 2017.

[117] A. Merendino, S. Dibb, M. Meadows et al., "Big data, big decisions: the impact of big data on board level decisionmaking," Journal of Business Research, vol. 93, pp. 67-78, 2018.

[118] C. Tu, X. He, Z. Shuai, and J. Fei, "Big data issues in smart grid - a review," Renewable and Sustainable Energy Reviews, vol. 79, pp. 1099-1107, 2017.

[119] L. Wen, K. Zhou, S. Yang, and L. Li, "Compression of smart meter big data: a survey," Renewable and Sustainable Energy Reviews, vol. 91, pp. 59-69, 2018. 
[120] M. Ge, H. Bangui, and B. Buhnova, "Big data for internet of things: a survey," Future Generation Computer Systems, vol. 87, pp. 601-614, 2018.

[121] Y. Huang, Z.-x. Chen, T. Yu, X.-z. Huang, and X.-f. Gu, "Agricultural remote sensing big data: management and applications," Journal of Integrative Agriculture, vol. 17, no. 9, pp. 1915-1931, 2018.

[122] L. Dawei, H. Anzi, and L. Gen, "Big data Technology: application and cases," in Handbook of Blockchain, Digital Finance, and Inclusion, vol. 2, pp. 65-82, Elsevier Inc., Amsterdam, Netherlands, 1st edition, 2018.

[123] T. Tong and H. Li, "Demand for MOOC-an application for Big Data," China Economic Review, vol. 51, pp. 194-207, 2017.

[124] J. Eckroth, "A course on big data analytics," Journal of Parallel Distributed Computing, 2018.

[125] T. D. Ngo, A. Kashani, G. Imbalzano, K. T. Q. Nguyen, and D. Hui, "Additive manufacturing (3D printing): a review of materials, methods, applications and challenges," Composites Part B: Engineering, vol. 143, pp. 172-196, 2018.

[126] R. Colella and L. Catarinucii, "Wearable UHF RFID sensor tag in 3D-printing technology for body temperature monitoring," in Proceedings of the 2nd URSI AT-RASC, pp. 3-6, Gran Canaria, Spain, 2018.

[127] M. Houwen, W. Tun, T. Jang et al., "Advances in technology for tissue engineering 3D printing of hydrogel composite Systems: recent advances in technology for tissue engineering," International Journal of Bioprinting, vol. 4, no. 1, p. 28, 2018.

[128] Y. Soliman, A. H. Feibus, and N. Baum, "Applications," Reviews in Urology, vol. 17, no. 1, pp. 20-24, 2015.

[129] A. Kotikian, R. L. Truby, J. W. Boley, T. J. White, and J. A. Lewis, "3D printing of liquid crystal elastomeric actuators with spatially programed nematic order," Advanced Materials, vol. 30, no. 10, Article ID 1706164, 2018.

[130] A. Zocca, P. Colombo, C. M. Gomes, and J. Günster, "Additive manufacturing of ceramics: issues, potentialities, and opportunities," Journal of the American Ceramic Society, vol. 98, no. 7, pp. 1983-2001, 2015.

[131] E.-B. Bae, K.-H. Park, J.-H. Shim et al., "Efficacy of rhBMP-2 loaded PCL/bdECM scaffold fabricated by 3D printing technology on bone regeneration," BioMed Research International, vol. 2018, Article ID 2876135, 12 pages, 2018.

[132] A. J. Cresswell-Boyes, A. H. Barber, D. Mills, A. Tatla, and G. R. Davis, "Approaches to 3D printing teeth from X-ray microtomography," Journal of Microscopy, vol. 272, no. 3, pp. 207-212, 2018.

[133] N. Vermeulen, G. Haddow, T. Seymour, A. Faulkner-jones, and W. Shu, "3D bioprint me: a socioethical view of bioprinting human organs and tissues," Journal of Medical Ethics, vol. 43, no. 9, pp. 618-624, 2017.

[134] X. Liu, H. Yuk, S. Lin et al., "3D printing of living responsive materials and devices," Advanced Materials, vol. 30, no. 4, Article ID 1704821, 2018.

[135] N. Subramanian and A. Jeyaraj, "Recent security challenges in cloud computing," Computers \& Electrical Engineering, vol. 71, pp. 28-42, 2018.

[136] M. García-Valls, A. Dubey, and V. Botti, "Introducing the new paradigm of social dispersed computing: applications, technologies and challenges," Journal of Systems Architecture, vol. 91, pp. 83-102, 2018.

[137] K. Njenga, L. Garg, A. Kumar, V. Prakash, and S. Bawa, "The cloud computing adoption in higher learning institutions in Kenya : hindering factors and recommendations for the way forward," Telematics and Informatics, vol. 38, pp. 225-246, 2018.

[138] O. Ali, A. Shrestha, J. Soar, and S. Wamba Fosso, "Cloud computing-enabled healthcare opportunities, issues, and applications: a systematic review," International Journal of Information Management, vol. 43, pp. 146-158, 2018.

[139] A. Vafamehr and M. E. Khodayar, "Energy-aware cloud computing," The Electricity Journal, vol. 31, no. 2, pp. 40-49, 2018.

[140] G. Graetz and G. Michaels, "Robots at work," The Review of Economics and Statistics, vol. 100, no. 5, pp. 753-768, 2018.

[141] D. Stavrou, S. Timotheou, C. G. Panayiotou, M. M. Polycarpou, S. Member, and M. M. Polycarpou, "Optimizing container loading with autonomous robots," IEEE Transactions on Automation Science and Engineering, vol. 15, no. 2, pp. 717-731, 2018.

[142] A. G. C. Gonzalez, M. V. S. Alves, G. S. Viana, L. K. Carvalho, and J. C. Basilio, "Supervisory control-based navigation architecture: a new framework for autonomous robots in industry 4.0 environments," IEEE Transactions on Industrial Informatics, vol. 14, no. 4, pp. 1732-1743, 2018.

[143] P. Gotovtsev, V. Vorobiev, A. Migalev et al., "Bioenergy based power sources for mobile autonomous robots," Robotics, pp. 1-18, 2018.

[144] C. B. Highley, K. H. Song, A. C. Daly, and J. A. Burdick, "Jammed microgel inks for 3D printing applications," Advanced Science, vol. 6, Article ID1801076, pp. 1-6, 2019.

[145] T. Jung and M. C. Tom Dieck, Augmented Reality and Virtual Reality; Empowering Human, Place and Business, Springer, Manchester, UK, 2018.

[146] P.-L. P. Rau, J. Zheng, Z. Guo, and J. Li, "Speed reading on virtual reality and augmented reality," Computers \& Education, vol. 125, pp. 240-245, 2018.

[147] ARC Insight, Immersive Training Simulator Enhances Safety on Total FPSOs, 2014.

[148] R. Palmarini, J. A. Erkoyuncu, R. Roy, and H. Torabmostaedi, “A systematic review of augmented reality applications in maintenance," Robotics and Computer-Integrated Manufacturing, vol. 49, pp. 215-228, 2018.

[149] S. Rho, A. V. Vasilakos, and W. Chen, "Cyber physical systems technologies and applications," Future Generation Computer Systems, vol. 56, pp. 436-437, 2015.

[150] L. Monostori, B. Kádár, T. Bauernhansl et al., "Cyberphysical systems in manufacturing," CIRP Annals, vol. 65, no. 2, pp. 621-641, 2016.

[151] D. Mourtzis, E. Vlachou, G. Dimitrakopoulos, and V. Zogopoulos, "Cyber- physical systems and education 4.0 -the teaching factory 4.0 concept," Procedia Manufacturing, vol. 23, pp. 129-134, 2018.

[152] O. Cardin, "Classification of cyber-physical production systems applications: proposition of an analysis framework," Computers in Industry, vol. 104, pp. 11-21, 2019.

[153] Y. Guo, X. Hu, B. Hu, J. Cheng, M. Zhou, and R. Y. K. Kwok, "Mobile cyber physical systems: current challenges and future networking applications," IEEE Access, vol. 6, pp. 12360-12368, 2018.

[154] D. Ding, Q.-L. Han, Y. Xiang, X. Ge, and X.-M. Zhang, “A survey on security control and attack detection for industrial cyber-physical systems," Neurocomputing, vol. 275, pp. 1674-1683, 2018.

[155] C. Krittanawong, H. Zhang, Z. Wang, M. Aydar, and T. Kitai, "Artificial intelligence in precision cardiovascular medicine," Journal of the American College of Cardiology, vol. 69, no. 21, pp. 2658-2664, 2017. 
[156] O. E. Agwu, J. U. Akpabio, S. B. Alabi, and A. Dosunmu, "Artificial intelligence techniques and their applications in drilling fluid engineering: a review," Journal of Petroleum Science and Engineering, 2018.

[157] J.-g. Li and K. Zhan, "Intelligent mining technology for an underground metal mine based on unmanned equipment," Engineering, vol. 4, no. 3, pp. 381-391, 2018.

[158] M. Zuccolotto, L. Fasanotti, S. Cavalieri, and C. E. Pereira, "Artificial immune intelligent maintenance system-diagnostic agents," IFAC Proceedings Volumes, vol. 47, no. 3, pp. 7116-7121, 2014.

[159] A. Mayr, M. Weigelt, M. Masuch, M. Meiners, F. Hüttel, and J. Franke, "Application scenarios of artificial intelligence in electric drives production," Procedia Manufacturing, vol. 24, pp. 40-47, 2018.

[160] Z. S. Y. Wong, J. Zhou, and Q. Zhang, "Artificial intelligence for infectious disease big data analytics," Infection, Disease \& Health, vol. 24, no. 1, pp. 44-48, 2019.

[161] S. J. Russell and N. Peter, Artificial Intelligence: A Modern Approach, Pearson, Harlow, England, 3rd edition, 2016.

[162] C. Manali and D. Srinu, "Study of smart sensors and their applications," International Journal of Advanced Research in Computer and Communication Engineering, vol. 3, no. 1, pp. 5031-5034, 2014.

[163] D. Spirjakin, A. Baranov, and S. Akbari, "Wearable wireless sensor system with RF remote activation for gas monitoring applications," IEEE Sensors Journal, vol. 18, no. 7, pp. 2976-2982, 2018.

[164] V. Agarwal, "Smart sensors for structural health monitoringoverview, challenges and advantages," Sensors \& Transducers, vol. 221, no. 3, pp. 1-8, 2018.

[165] V. F. Cardoso, D. M. Correia, C. Ribeiro, M. M. Fernandes, and S. Lanceros-m, "Fluorinated polymers as smart materials for advanced biomedical applications," Polymers, vol. 161, no. 10, pp. 1-26, 2018.

[166] A. S. Fiorillo, C. D. Critello, and A. S. Pullano, "Theory, technology and applications of piezoresistive sensors: a review," Sensors \& Actuators, vol. 281, pp. 156-175, 2018.

[167] M. U. Hagera, K. L. Krishna, and K. Anuradha, "Implementation of smart home automation with enhanced security," International Journal of Scientific Research in Science, Engineering and Technology, vol. 4, no. 4, pp. 528-532, 2018.

[168] O. Alvear, C. T. Calafate, J. Cano, and P. Manzoni, "Crowdsensing in smart Cities: overview, platforms and environment sensing issues," Sensors, vol. 460, no. 18, pp. 1-28, 2018.

[169] K. Harold and A. Randal, Simulation of Dynamic Systems with Matlab and Simulink, Taylor \& Francis, Boca Raton, FL, USA, 3rd edition, 2018.

[170] L. Xiang, "Simulation system of car crash test in C-NCAP analysis based on an improved apriori algorithm," Physics Procedia, vol. 25, pp. 2066-2071, 2012.

[171] J. Xu, B.-K. Li, and S.-M. Luo, "Practice and exploration on teaching reform of engineering project management course in universities based on BIM simulation technology," EURASIA Journal of Mathematics, Science and Technology Education, vol. 14, no. 5, pp. 1827-1835, 2018.

[172] V. Vuckovic, V. V. Mitic, L. Kocic, B. Arizanovic, V. Paunovic, and R. Nikolic, "Tesla's fountain-modeling and simulation in ceramics technology," Journal of the European Ceramic Society, vol. 38, no. 8, pp. 3049-3056, 2018.

[173] R. M. Nataraja, N. Webb, and P. J. Lopez, "Simulation in paediatric urology and surgery, part 2: an overview of simulation modalities and their applications," Journal of Pediatric Urology, vol. 14, no. 2, pp. 125-131, 2018.

[174] F. Bonchi, A. Brogi, A. Canciani, and J. Soldani, "Science of computer programming simulation-based matching of cloud applications," Science of Computer Programming, vol. 1, pp. 1-22, 2017.

[175] K. Yu, Q. Cao, and L. Zhou, "Study on qualitative simulation technology of group safety behaviors and the related software platform," Computers \& Industrial Engineering, vol. 127, pp. 1037-1055, 2018.

[176] K. L. Garner, S. Suh, and A. A. Keller, “Assessing the risk of engineered nanomaterials in the environment: development and application of the nanoFate model," Environmental Science \& Technology, vol. 51, no. 10, pp. 5541-5551, 2017.

[177] M. Vinardell, H. Llanas, L. Marics, and M. Mitjans, "In vitro comparative skin irritation induced by nano and non-nano zinc oxide," Nanomaterials, vol. 7, no. 3, p. 56, 2017.

[178] T. Singh, S. Shukla, P. Kumar, V. Wahla, and V. K. Bajpai, "Application of nanotechnology in food science: perception and overview," Frontiers in Microbiology, vol. 8, pp. 1-7, 2017.

[179] M. Pal, "Nanotechnology: a new approach in food packaging," Journal of Food: Microbiology, Safety \& Hygiene, vol. 2, no. 2, pp. 8-9, 2017.

[180] A. P. Nikalje, "Nanotechnology and its applications in medicine," Medicinal Chemistry, vol. 5, no. 2, pp. 81-89, 2015.

[181] V. Chauhan, V. Singh, and A. Tiwari, "Applications of nanotechnology in forensic investigation," International Journal of Life-Sciences Scientific Research, vol. 3, no. 3, pp. 1047-1051, 2017.

[182] A.-S. Nizami and M. Rehan, "Towards nanotechnologybased biofuel industry," Biofuel Research Journal, vol. 5, no. 2, pp. 798-799, 2018.

[183] S. Nummelin, J. Kommeri, M. A. Kostiainen, and V. Linko, "Evolution of structural DNA nanotechnology," Advanced Materials, vol. 30, no. 24, Article ID 1703721, 2018.

[184] M. Wang, G. Mi, D. Shi, N. Bassous, D. Hickey, and T. J. Webster, "Nanotechnology and nanomaterials for improving neural interfaces," Advanced Functional Materials, vol. 28, Article ID 1700905, pp. 1-28, 2018.

[185] R. V. Ulijn and R. Jerala, "Peptide and protein nanotechnology into the 2020s: beyond biology," Chemical Society Reviews, vol. 47, no. 10, pp. 3391-3394, 2018.

[186] B. Vergouw, H. Nagel, G. Bondt, and B. Custers, "Drone technology: types, payloads, applications, frequency spectrum issues and future developments," in The Future of Drone Use, Information Technology and Law Series 27, pp. 21-46, T.M.C Asser Press, Hague, Netherlands, 2016.

[187] P. Kardasz, J. Doskocz, M. Hejduk, P. Wiejkut, and H. Zarzycki, "Drones and possibilities of their using," Journal of Civil \& Environmental Engineering, vol. 6, no. 3, pp. 1-7, 2016.

[188] G. Vásárhelyi, C. Virágh, G. Somorjai, and T. Nepusz, "Optimized flocking of autonomous drones in confined environments," Science Robotics, vol. 3, no. 20, Article ID eaat3536, 2018.

[189] PwC and Agoria, A Drone's Eye View: Overview of the Belgian UAV Ecosystem \& the Development of Commercial Drone Application in Belgium, 2018.

[190] FAO and ITU, E-agriculture in Action: Drones for Agriculture, FAO, Bangkok, Thailand, 2018.

[191] S. G. Potts, P. Neumann, B. Vaissière, and N. J. Vereecken, "Science of the total environment robotic bees for crop 
Pollination: why drones cannot replace Biodiversity," Science of the Total Environment, vol. 642, pp. 665-667, 2018.

[192] A. Otto, N. Agatz, J. Campbell, B. Golden, and E. Pesch, "Optimization approaches for civil applications of unmanned aerial vehicles (UAVs) or aerial drones: a survey," Networks, vol. 72, no. 4, pp. 411-458, 2018.

[193] M. Hassanalian, D. Rice, and A. Abdelkefi, "Evolution of space drones for planetary exploration: a review," Progress in Aerospace Sciences, vol. 97, pp. 61-105, 2018.

[194] J. C. Hodgson, R. Mott, S. M. Baylis et al., "Drones count wildlife more accurately and precisely than humans," Methods in Ecology and Evolution, vol. 9, no. 5, pp. 11601167, 2018.

[195] World Economic Forum (WEF), Harnessing the Fourth Industrial Revolution for the Earth, World Economic Forum (WEF), Cologny, Switzerland, 2017.

[196] A. W. Betten, J. E. W. Broerse, and F. Kupper, "Dynamics of problem setting and framing in citizen discussions on synthetic biology," Public Understanding of Science, vol. 27, no. 3, pp. 294-309, 2018.

[197] H. D. Goold, P. Wright, and D. Hailstones, "Emerging opportunities for synthetic biology in agriculture," Genes, vol. 341, no. 9, pp. 1-17, 2018.

[198] E. Wurtzel, "Carotenoids and synthetic biology," The American Society of Plant Biologists, 2018.

[199] D. Acemoglu and P. Restrepo, Artificial Intelligence, Automation and Work, Working Paper No. 24196, 2018.

[200] M. J. Sousa and Á. Rocha, "Skills for disruptive digital business," Journal of Business Research, vol. 94, pp. 257-263, 2018.

[201] G. Smith and C. Talent, "The intelligent solution: automation, the skills shortage and cyber-security," Computer Fraud \& Security, vol. 2018, no. 8, pp. 6-9, 2018.

[202] KPMG, The Factory of the Future Industry 4.0 - the Challenges of Tomorrow, KPMG, Amstelveen, Netherlands, 2016.

[203] N. W. Gleason, Higher Education in the Era of the Fourth Industrial Revolution, Palgrave Macmillan, Singapore, 2018.

[204] A. van der Zeeuw, A. Jam, V. Deursen, and G. Jansen, "Inequalities in the social use of the internet of things: a capital and skills perspective," New Media \& Society, vol. 21, no. 6, pp. 1344-1361, 2019.

[205] EEF, The Fourth Industrial Revolution- A Primer for Manufacturers, EEF, London, UK, 2016.

[206] W. Schroeder, Germany's Industry 4.0 Strategy; Rhine Capitalism in the Age of Digitalisation, FES, London, UK, 2016.

[207] S. M. Sackey and A. Bester, "Industrial engineering curriculum in industry 4.0 in a South African context," South A Frican Journal of Industrial Engineering, vol. 27, no. 4, pp. 101-114, 2016.

[208] C. Selim, K. Yasanur, and G. Eray, "Adapting engineering education to industry 4.0 vision," Technologies, vol. 7 , no. 1 , p. 10, 2019.

[209] M. A. Peters, "Technological unemployment: educating for the fourth industrial revolution," Educational Philosophy and Theory, vol. 49, no. 1, pp. 1-6, 2017.

[210] K. Lensing and J. Friedhoff, "Designing a curriculum for the internet-of-things-laboratory to foster creativity and a maker mindset within varying target groups," Procedia Manufacturing, vol. 23, pp. 231-236, 2018.

[211] G. Santoro, D. Vrontis, A. Thrassou, and L. Dezi, "The internet of Things : building a knowledge management system for open innovation and knowledge management capacity,"
Technological Forecasting \& Social Change, vol. 136, pp. 347-354, 2017.

[212] P. Maresova, I. Soukal, L. Svobodova et al., "Consequences of industry 4.0 in business and economics," Economies, vol. 46, no. 6, pp. 1-14, 2018.

[213] M. Piccarozzi and B. Aquilani, "Industry 4.0 in management studies: a systematic literature review," Sustainability, vol. 3821, no. 10, pp. 1-24, 2018.

[214] T. J. Lopez-Garcia1, J. A. Alvarez-Cedillo1, T. A. Sanchez, and C. M. Vicario-Solorzano, "Review of trends in the educational model of distance education in Mexico, towards an education 4.0," Computer Reviews Journal, vol. 3, pp. 111$121,2019$.

[215] C. C. Chea, J. Tan, and J. Huan, "Higher education 4.0 : the possibilities and challenges," Journal of Social Sciences and Humanities, vol. 5, no. 2, pp. 81-85, 2019.

[216] A. A. Hussin, "Education 4.0 made Simple: ideas for teaching," International Journal of Education \& Literacy Studies, vol. 6, no. 3, p. 92, 2018.

[217] A. Hariharasudan and S. Kot, "A scoping review on digital English and education 4.0 for industry 4.0," Social Sciences, vol. 7 , no. 11, p. 227, 2018.

[218] S. H. Halili, "Technological advancemnts in education 4.0," The Online Journal of Distance Education and E-Learning, vol. 7, no. 1, pp. 63-69, 2019.

[219] M. Maria, F. Shahbodin, and N. C. Pee, "Malaysian higher education system towards industry 4.0 - current trends overview," in Proceedings of the 3rd International Conference on Applied Science and Technology (ICAST'18), Georgetown, Malaysia, 2018.

[220] V. Puncreobutr, "Education 4.0: new challenge of learning," St. Theresa Journal of Humanities and Social Sciences, vol. 2, no. 2, pp. 1-4, 2016.

[221] I. Zolotová, P. Papcun, E. Kajáti, M. Miškuf, and J. Mocnej, "Smart and cognitive solutions for operator 4.0: laboratory H-CPPS case studies," Computers \& Industrial Engineering, vol. 139, Article ID 105471, 2018.

[222] D. Romero, P. Bernus, O. Noran, J. Stahre, and Å. Fastberglund, "The operator 4.0 : human cyber-physical systems $\&$ adaptive automation towards human-automation symbiosis work systems," in Proceedings of the International Conference on Computers and Industrial Engineering (CIE46), pp. 1-11, Tianjin, China, 2016.

[223] OECD, OECD Future of Education and Skills 2030: Project Background, OECD, Paris, France, 2019.

[224] FICCI-EY, Leapfrogging to Education 4.0: Student at the Core, New Delhi, India, 2017.

[225] B. Schallock, C. Rybski, R. Jochem, and H. Kohl, "Learning factory for industry 4.0 to provide future skills beyond technical training," Procedia Manufacturing, vol. 23, pp. 27-32, 2018.

[226] M. Hulla, M. Hammer, H. Karre, C. Ramsauer, and P. Afonso, "A case study based digitalization training for learning factories," Procedia Manufacturing, vol. 31, pp. 169-174, 2019.

[227] D. Mavrikios, K. Georgoulias, and G. Chryssolouris, "The teaching factory Paradigm: developments and outlook," Procedia Manufacturing, vol. 23, pp. 1-6, 2018.

[228] E. Rauch, F. Morandell, and D. T. Matt, "AD design guidelines for implementing I4.0 learning factories," Procedia Manufacturing, vol. 31, pp. 239-244, 2019.

[229] D. Mourtzis, D. Tsakalos, F. Xanthi, and V. Zogopoulos, "Optimization of highly automated production line: an 
advanced engineering educational approach," Procedia Manufacturing, vol. 31, pp. 45-51, 2019.

[230] B. Salah, M. H. Abidi, S. H. Mian, M. Krid, H. Alkhalefah, and A. Abdo, "Virtual reality-based engineering education to enhance manufacturing sustainability in industry 4.0," Sustainability, vol. 11, no. 1477, pp. 1-19, 2019.

[231] E. Kaasinen, S. Aromaa, P. Heikkilä1, and M. Liinasuo, "Empowering and engaging solutions for operator 4.0," in Acceptance and Foreseen Impacts by Factory Workers, pp. 615-623, Springer, Berlin, Germany, 2019.

[232] T. Ruppert, S. Jaskó, T. Holczinger, and J. Abonyi, "Enabling technologies for operator 4.0: a survey," Applied Sciences, vol. 8, no. 9, p. 1650, 2018.

[233] ACE Factories, Human-Centred Factories from Theory to Industrial Practice, Lessons Learned And Recommendations, 2019.

[234] M. Golan, Y. Cohen, and G. Singer, "A framework for operator-workstation interaction in industry 4.0," International Journal of Production Research, vol. 1-12, 2019. 